\title{
Governance, Human Security, Safety and Rule of Law in Nigeria's Fourth Republic from the Twin Eye of WGI and IIAG
}

\author{
Tunde ABIORO, PhD \\ Department of Local Government Studies \\ Obafemi Awolowo University, Ile- Ife, Nigeria \\ Tunji DARAMOLA \\ Department of Political Science \\ Ekiti State University, Ado Ekiti, Nigeria
}

Received: May 6, 2018 Accepted: June 4, 2018 Online published: June 24, 2018

doi:10.5296/jpag.v8i2.13092ＵRL: https://doi.org/10.5296/jpag.v8i2.13092

\begin{abstract}
Safety and Rule of Law has been on persistent trial in Nigeria since the independence of 1960 and the return to democratic governance of the republic for the fourth time in 1999 after several military interregnums did not abate the experience. It plays out through attacks on the judicial system, denial of citizens to official information, threats to personal lives as well as civil and domestic armed conflicts among others. The study examines the indicator performance and perception of Nigerian government in Overall Governance (OG) as well as Safety and Rule of Law. It seeks to achieve this through the examination of the World Governance Index (WGI) and Ibrahim Index of African Governance (IIAG) data. The data were generated from continental, global and institutional documents. The study found out there is deficit and gap between the government and the citizens with evidence in the negative perception and performance recorded. It thus suggests the strengthening of democratic institutions, enhancement of rule of law, combating corruption, improving social service delivery to lessen the threats of human and national security as well as governmental openness for improved participation, involvement and improved delivery by government across the levels of government.
\end{abstract}

Keywords: governance, safety, rule of law, WGI and IIAG 


\section{Introduction}

Literature is replete with studies on governance and human security both by individuals and research institutions (Abioro, 2016; Fukuyama, 2013; Institute for Security Studies, 2013; Omodia and Aliu, 2013; Okeke, 2010; Kaufmann, 2010; Raeymaekers, Menkhanus and Vlassenroot 2008; European Commission, 2006; Akokpari, 2007; Thomas, 2006; Hope, 2005 among others), expressing local, national, international as well as multinational conception towards understanding the concepts. However, Henk (2001) expresses that attempts to develop new and innovative security paradigms specifically relevant to African contexts are relatively recent while Hutchful and Fayemi (2004) argue there are antecedents of the concept of human security to be found long ago in African philosophies and discourses.

No doubt, human security and governance are contested concepts. On the one hand, there is consensus among the proponents of human security that the referent object of security should be the individual rather than the state, but no consensus with respect to the threats to individuals that should be included under the human security rubric (Humanitarian Policy and Conflict Research, 2001), while on the other hand, Kaufmann and Kray, (2010) states that although the concept of governance is widely discussed among policymakers and scholars, there is yet no strong consensus around a single definition of governance or institutional quality. This has really opened the concepts to debates and academic evaluation. The concern here thus remains the facilitation of self nourishing relationship between human, regime and state security in Nigeria showing also the legitimate relations between the government and the governed.

African continent presents a mosaic of progressive, regressive, retarded and stagnant states as more than half of Africa's countries are at risk of facing peace and security crises in the form of state collapse, weak states, civil wars, ethnic massacres, and social and political deprivations of its citizens Sharamo and Ayangafac (2011). Meanwhile, many of the challenges are visible within the nation- Nigeria.

This study explicates the links between governance and human security on one part; safety and rule of law of the Nigerian government on the other hand. It aims to contribute a few pieces of the complex and multidimensional issues by increasing the awareness of government at all levels towards creating an institutional structure that can impact the citizens through responsive and effective human security system as well as effective and efficient safety and rule of law. The objective is not merely to document the phenomenon of governance, human security, safety and rule of law in Nigeria, but we hope to contribute to the discourse and awake consciousness and efforts to theorize and situate it in the context of political and social concern and ultimately change to reshape Nigeria and the continent, Africa. The paper is divided into six sections that include: introduction; conceptual clarification of human security, governance and rule of law; research approach and method; empirical exploration; assessment of the Nigerian nation in the fourth republic precedes the findings and closing remarks. 


\section{Conceptual and Theoretical Issues}

\subsection{Understanding Governance}

In the past few decades, the term governance has received wide recognition owing to its relevance in local, national and international developments. However, there still exists a lack of conceptual consensus as various individuals, bodies and organisations have defined it to suite various purposes they stand for and this has been either through the government institutions, society, environment or individual perceptions. Individuals that have conceptualized the term include Fukuyama (2013) who opines that governance is the ability of government to make and enforce rules, and to deliver services, regardless of whether that government is democratic or not. In other words, governance has to do with the ability to exercise authority in providing services for the people in a given nation; irrespective of the form of government in operation. It can be defined as the process of exercising political, economic and administrative authority, especially over a state. In what IIGA (2017) described as the provision of the political, social and economic public goods and services that every citizen has the right to expect from their state, and that a state has the responsibility to deliver to its citizens.

Embodied in governance are also mechanisms, processes and institutions put in place through which citizens articulate interests, exercise their legal rights, meet their obligations and meditate their differences. Okeke (2010) asserts that governance could be said to have evolved from the need to organize society towards the achievement of common goal. An opinion, worth considering is that society derives its roots from the solitary man who later got transformed into a family person to fulfill the need for socialization (Abioro, 2016). Within this union, he enjoyed the love, care and company of family members and recognized their inherent and inalienable rights in order to preserve the love, harmony and cohesion within the family. Thereafter, society grew out of the family in response to the need to fulfill other higher needs and the collective aspirations of the people such as security, economic well-being and survival, through negotiations and the formation of social contract between the government and the governed. Modern state thus emerged as the most perfect machinery to be created by man in his intellectual, socio-economic, political and cultural history for his well-being and happiness.

According to Kaufmann (2005) governance should be seen as the traditions and institutions by which authority in a country is exercised for the common good and should entail the purposes for dimension - this is the process by which those in authority are selected, monitored, and replaced; the economic dimension - which is government's capacity to effectively manage its resources and implement sound policies; and the institutional dimension - viewed from the perspective of respect for the citizens and the state for the country's institution. In not too distance line, Hope (2005) contends that governance is about the manner in which responsibility is discharged; such a responsibility could be acquired through election, selection, appointment or delegation in the public domain.

Institutionally, the United Nations (1997) sees it as the manner in which power is exercised in the management of a country's economic and social development. Of note, the European 
Commission (2006) captures the perspective this study lean towards when it avers that governance concerns the state's ability to serve the citizens. It refers to the rules, processes and behaviour by which interests are articulated, resources are managed, and power is exercised in society. Also, the United States Agency for International Development USAID (2009) asserts that governance issues pertain to the ability of government to develop an efficient, effective and accountable public management process that is open to citizen's participation and that strengthens rather than weaken a democratic system of government. From the descriptions above, the elements that run through are states, citizens, interests, participation, distribution and regulation. Meanwhile, the Decentralization Finance and Management Project (1997) states the qualities of governance to include; managerial and organizational efficiency, accountability, legitimacy and responsiveness to the public, as well as, transparency in decision making and pluralism in policy options and choices.

However, political accountability; freedom of association and participation; reliable and equitable legal frameworks; bureaucratic transparency; availability of valid information; and effective - efficient public sector management are core elements of governance (United Nations Development Programme, 1995). This position was however modified in 1997 to contain the underlying characteristics of good governance as; participation, rule of law, transparency, responsive, conscious orientation, equity, effective and efficiency, accountability and strategic vision. In a similar exposition, the WGI (2010) lists the six indicators of good governance to include: voice and accountability (citizen participation, independent media); political instability and violence (threat of state coup); government effectiveness (quality of civil service); regulatory burden (market-unfriendly policies); rule of law (perceptions of crime, effective judiciary, enforceable contracts); and corruption (perception of corruption).

\subsection{The Concept of Human Security}

The concept was popularized by United Nation Commission Report (2003) and United Nation Development Programme report of (1994: 20-24) where it expressly identify human security to involve two main components: freedom from fear and freedom from want which has further been broken into: economic security (access to employment and earning basic income on a sustained basis), food security (economic and physical access to food and balanced nutrition), health security (access to health facilities, medical care and basic drugs as well as protection from communicable and non-communicable diseases), environmental security (protection of the environment and natural resources as well as exploiting without compromising its use for future generations), personal security (freedom from physical violence caused by either the state, groups or individuals), community security (freedom to belong to a community or communities) and political security (freedom to hold political views, subscribe to ideologies, belong and express political views).

Specifically, human security concept challenges the idea of state dominance in international relations and subsequently as the main referent of security. It de-emphasizes the state and focuses on the people. However, Lodgaard (2000) argues the constraints on the state sovereignty, the mobilization of international civil society in defence of international norms 
and the sharing of power between the state and the non-state actors leaves a clear message that the state can no longer monopolize the concept and practice of security. Thus, it is based on the state meeting its responsibilities on the citizens by providing security against social and political environment while also considering social and economic needs.

As earlier mentioned, human security attempts to shift attention from the state to people as the key referent of security matters. The shift comes against a background of the dominance of a security concept that was defined in relation to the territorial state based on the UN Charter where security of the state primarily means the preservation of territorial integrity, respect for the sovereignty of states, non-interference in the domestic affairs of states, and the sovereign equality of states. This realist conception now referred to as the traditional notion of security appear ethnocentric, parochial and narrowly focused (Henk, 2005; Oberleitner, 2005). Regrettably, until recently in Nigeria, threats to security is primarily seen as external in source and, by implication, relied on military might to respond to such. This however made the desire by the Nigerian-state to protect their borders overshadows the social, economic, political and environmental threats facing the citizenry (Akokpari, 2007, UNDP 2004). Thus, the pre-eminence of human security suggest a departure from the traditional meaning of security, which focused primarily on the state.

\subsection{Rule of Law in Perspective}

Like many other social concepts, Rule of Law suffers from conceptual agreement but no doubt has its balance and restraints. The phrase "Rule of Law" is derived from the French phrase 'la principe de legalite; (the principle of legality), which connotes that the state be governed, not by the ruler or the nominated representatives of the people but by the law. Today, it is comprised of an intricate chain of fundamental ideas, which include but not limited to equal treatment before the law for government and the governed; the independence of the judiciary; transparency, consistency, and accountability in the administration of law; and the notions of equity, justice and fairness; legal certainty, prevention of abuse (misuse) of power (Alok, nd; Tamanaha, 2007; Venice Commission and Council of Europe, 2016).

The United Nations in the 2005 Outcome Document of the World Summit opines it is a concept of universal validity that emphasizes universal adherence to and implementation of it at national and international levels making it a global ideal and aspiration. However, Tamanaha (2007) identified its two basic functions to include: to impose legal restraints on government officials and to maintain order and coordinate behaviour and transactions among citizens.

It suffices to submit that any definition of the rule of law will have to incorporate all of the following four principles: (1) the principle that power may not be exercised arbitrarily. This principle requires a rejection of the rule by man and the notion that laws should be prospective, accessible, and clear; (2) the principle of supremacy and independence of the law. This principle distinguishes the rule of law and requires acceptance of the principle of the separation of powers, which is the idea that the law applies to all, including the sovereign, and that there must be provisions for an independent institution, such as a judiciary, to apply the law to specific cases; (3) the principle that the law must apply to all persons equally, 
offering equal protection without discrimination. This principle requires that the law should be of general application and command compliance and obedience; and (4) the principle of respect for universal human rights as laid down in the instruments and conventions accepted by the international community as a whole (Anuye, Paul, Ityavkasa, and Deji; 2017 and; Gosalbo-Bono, 2010). These principles, if successfully implemented within the state, will result in national stability which will, in turn guarantee good governance and security of individuals.

The primary, major and consistent reason advanced for the importance of the rule of law is that it is inherently necessary to support the emergence of democracy (Hager, 2000). Thus, there has long been a consensus at least among Western scholars that it is not possible to have a genuinely functioning democracy without having in place a system that adheres to the rule of law. In operation, it is linked not only to human rights but also to democracy which relates to the involvement of the people in the decision making process in the society.

\section{Research Approach and Method}

The study adopts quantitative research involving existing data sourced from WGI and IIAG documents. While WGI methodology adopts the combination of views of large number of enterprises, citizens and expert survey respondents in industrial and developing countries/regions from 30 individual data sources produced by a variety of survey institutes, think tanks, non-governmental organisations, international organisations as well as the private sectors (http://info.worldbank.org/governance/wgi/index.asp-reports), the IIAG focuses on measuring output and outcome of policy rather than the declaration of intent, de jure statutes and level of expenditure for measuring governance performance across all the dimensions for 54 African countries (IIAG, 2017). The indicators used were collected with 177 variables that measured governance concepts from 36 independent sources.

Of note, the indicators from WGI were measured by voice and accountability; political instability and violence; government effectiveness; regulatory burden; rule of law; and corruption while OG measure of IIAG on safety and rule of law were with indicators such as: rule of law; accountability; personal safety; and national security. The study focus was on the performance and perception in areas of governance, safety and rule of law in Nigeria and data were subjected to content analysis. 


\section{Empirical Exploration}

Table 1. Governance Indicators, 2006, Some Regions

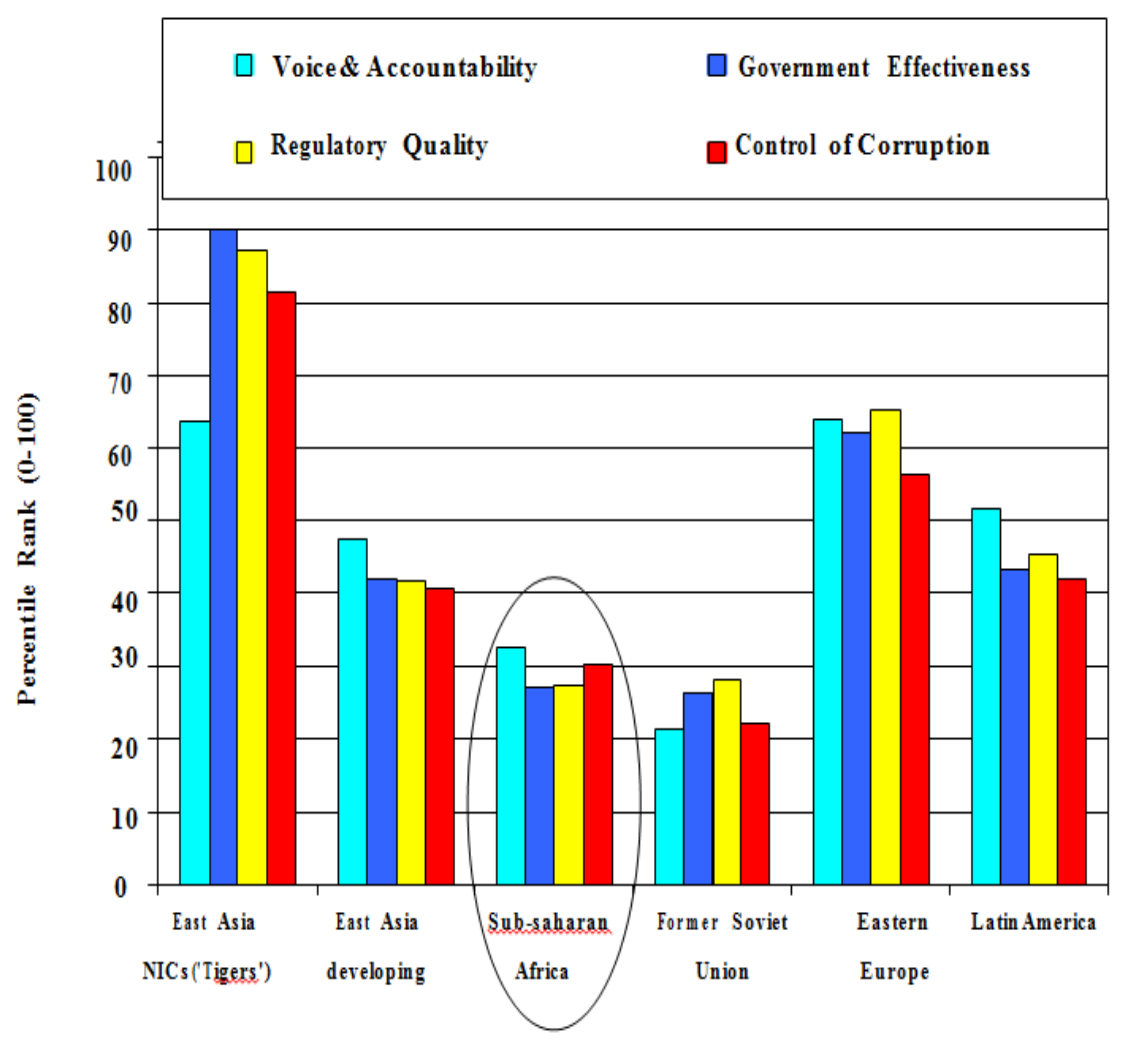

Source: 'Governance Matters VI: Governance Indicators for 1996-2006', by D. Kaufmann, A. Kraay and M. Mastruzzi, June 2007 - www.govindicators.org

Table 1 presents governance in some regions across the world using four indicators: voice and accountability; government effectiveness; regulatory quality; and control of corruption. Generally, governance in Former Soviet Union is reported not to fare well as all indicators ranked below 30\%. Meanwhile, East Asia developing region and Latin America as presented in the chart, averaged about $50 \%$ in the indicators with only East Asia NICs (Tigers) and Eastern Europe averaging above 50\%. Sub-Saharan Africa followed in close line with the indicators averaging about $29 \%$. In this region, voice \& accountability rated about $33 \%$, government effectiveness $27 \%$, regulatory quality $28 \%$ and control of corruption at $30 \%$ respectively. 
Governance in Sub-Saharan Africa

Table 2. Resource-Rich vs. Non Resource Rich Countries, 2006

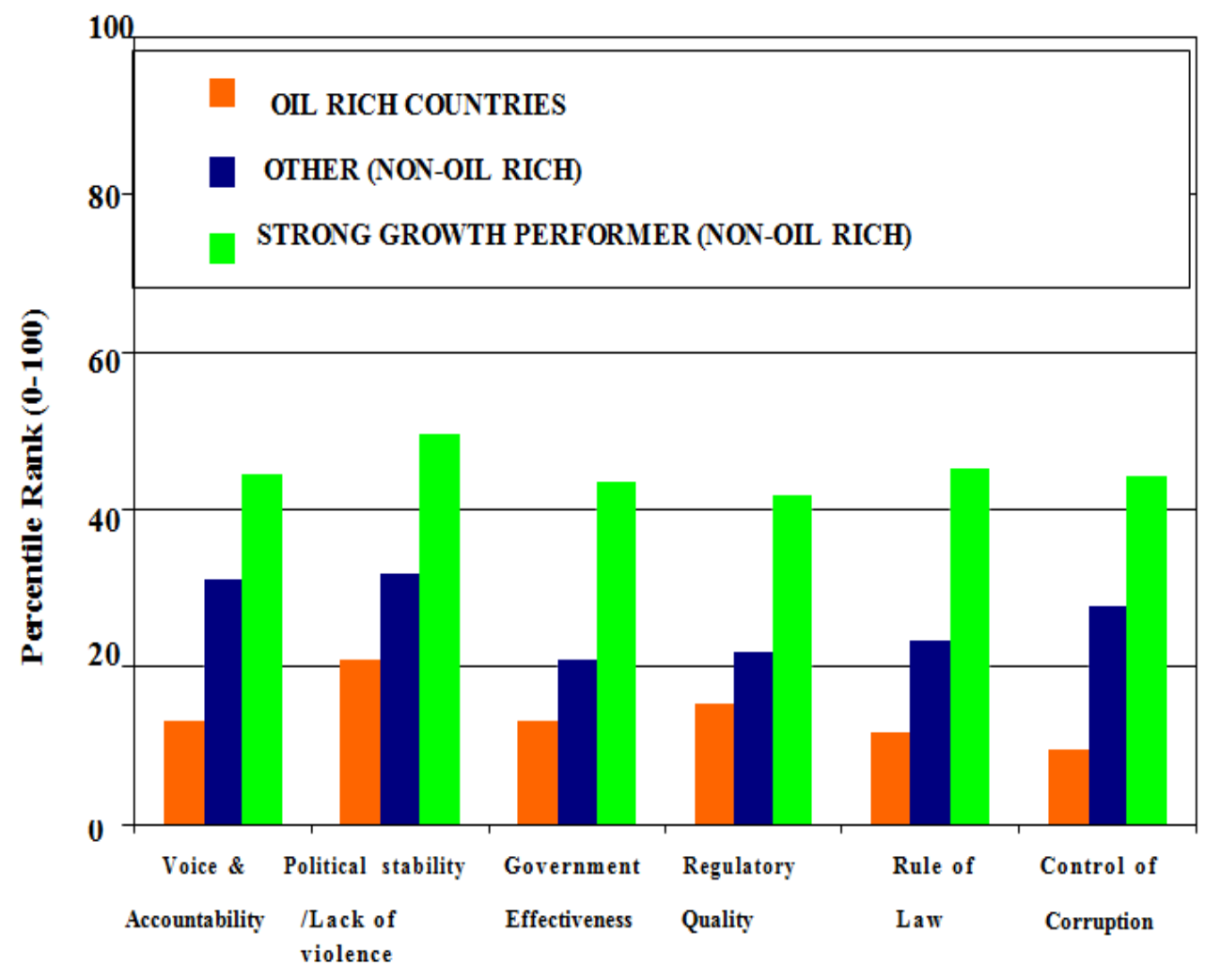

Source: 'Governance Matters VI: Governance Indicators for 1996 - 2006', by D. Kaufmann, A. Kraay and M. Mastruzzi, June 2007 - www.govindicators.org.

Note: Oil Rich Countries included Gabon, Congo, Nigeria, Chad, Sudan, Angola and Equitorial Guinea

Table 2 presents the percentile rating of governance indicators in resource-rich and non-resource rich countries in Sub-Saharan Africa from 1996 to 2006. In terms of voice and accountability, non-oil rich countries were reported to rank higher with about $29 \%$ compared to their oil-rich counterparts with $15 \%$ while non-oil rich countries with strong growth performance recording about $45 \%$. Political stability and lack of violence was reportedly lowest $(21 \%)$ in oil rich countries but lower $(30 \%)$ in non-oil rich countries while it was reported to be low (46\%) in strong growth performing non-oil rich countries. The effectiveness of government was lowest $(15 \%)$ in oil rich countries, lower $(21 \%)$ in non-oil rich and low (43\%) in strong growth performing non-oil rich countries. Regulatory quality was also reported as lowest $(17 \%)$ in oil rich countries, lower $(22 \%)$ in non-oil rich and low $(41 \%)$ in strong growth performing non-oil rich countries. Rule of law in oil rich countries was lowest $(11 \%)$, lower $(23 \%)$ in non-oil rich countries and low $(44 \%)$ in strong growth performing non-oil rich nations. Control of corruption was reportedly lowest (10\%) in oil rich countries, lower (26\%) in non-oil rich countries and low (43\%) in non-oil rich countries with strong growth performance respectively. 
Table 3. The Overall Governance Performance

\begin{tabular}{l|l|l|l|l|l|l}
\hline $\begin{array}{l}2016 \\
\text { Rank/54 }\end{array}$ & $\begin{array}{l}2016 \\
\text { Score/100.0 }\end{array}$ & $\begin{array}{l}\text { 10-Year } \\
\text { Trend } \\
(2007-2016)\end{array}$ & $\begin{array}{l}\text { Annual } \\
\text { average trend } \\
(2007-2016)\end{array}$ & $\begin{array}{l}5-\text { Year } \\
\text { Trend } \\
(2012-2016)\end{array}$ & $\begin{array}{l}\text { Annual } \\
\text { Average Trend } \\
(2012-2016)\end{array}$ & $\begin{array}{l}\text { Indicator } \\
\text { performance }\end{array}$ \\
\hline $\begin{array}{l}1 \\
\text { Mauritius }\end{array}$ & 81.4 & +3.1 & +0.34 & -0.5 & -0.13 & $\begin{array}{l}\text { Warning } \\
\text { Signs }\end{array}$ \\
\hline $\begin{array}{l}35 \\
\text { Nigeria }\end{array}$ & 48.1 & +34 & +0.38 & +3.3 & +0.83 & $\begin{array}{l}\text { Increasing } \\
\text { Improvement }\end{array}$ \\
\hline $\begin{array}{l}54 \\
\text { Somalia }\end{array}$ & 11.6 & +0.7 & +0.08 & +1.4 & +0.35 & $\begin{array}{l}\text { Increasing } \\
\text { Improvement }\end{array}$ \\
\hline $\begin{array}{l}\text { African } \\
\text { Average }\end{array}$ & 50.8 & +1.4 & +0.16 & +0.4 & +0.10 & $\begin{array}{l}\text { Slowing } \\
\text { improvement }\end{array}$ \\
\hline
\end{tabular}

Source: IIAG, 2017.

Note 1: if annual trend appears the same in the two time periods, differences may exist beyond the 2nd decimal place. Note 2: For relevance and specification, the Nigeria data were singled for explanation and analysis. Also, for comparism, the first and last countries in the ratings were listed in the table.

The overall governance is measured by safety and rule of law; participation and human rights; sustainable economic opportunity; and human development. Generally, the African continent has, on average, been improving in Overall Governance (OG). Looking back over the last decade (2007-2016), the African average score has improved by +1.4 score points from 49.4 (out of 100.0, see IIAG, 2017: 18) to 50.8, reaching in 2016 its highest score since the IIAG's first data year (2000). However, while OG has improved over the last decade at an average yearly rate of +0.16 , over the latter part of this period (the last five years, 2012-2016), the pace of progress has slowed down, improving only at an average yearly rate of +0.10 . Nigeria however ranked 35th of 54 African countries examined with 48.1/100.0 from +34 earlier recorded in (2007-2016). It also has an annual average trend of +0.38 and +3.35 year trend (2012-2016) with average annual trend of the same period as +0.83 .

Table 4. Safety and Rule of Law

\begin{tabular}{c|c|c|c|c|l|l}
\hline $\begin{array}{l}2016 \\
\text { Rank/54 }\end{array}$ & $\begin{array}{l}2016 \\
\text { Score/100.0 }\end{array}$ & $\begin{array}{l}\text { 10-Year } \\
\text { Trend } \\
(2007-2016)\end{array}$ & $\begin{array}{l}\text { Annual } \\
\text { Average } \\
\text { Trend } \\
(2007-2016)\end{array}$ & $\begin{array}{l}\text { 5-Year } \\
\text { Trend } \\
(2012-2016)\end{array}$ & $\begin{array}{l}\text { Annual } \\
\text { Average } \\
\text { Trend } \\
(2012-2016)\end{array}$ & $\begin{array}{l}\text { Indicator } \\
\text { performance }\end{array}$ \\
\hline $\begin{array}{c}1 \\
\text { Mauritius }\end{array}$ & 82.7 & +2.0 & +0.22 & -0.6 & -0.15 & Warning signs \\
\hline 37 Nigeria & 46.4 & -3.5 & -0.39 & +4.0 & +1.00 & $\begin{array}{l}\text { Bouncing } \\
\text { back }\end{array}$ \\
\hline 54 Somalia & 8.5 & -0.3 & -0.03 & -0.6 & -0.15 & $\begin{array}{l}\text { Increasing } \\
\text { deterioration }\end{array}$ \\
\hline $\begin{array}{c}\text { African } \\
\text { Average }\end{array}$ & 52.8 & -2.4 & -0.27 & -0.7 & -0.18 & $\begin{array}{l}\text { Slowing } \\
\text { deterioration }\end{array}$ \\
\hline
\end{tabular}

Source: IIAG, 2017.

Note 1: if annual trend appears the same in the two time periods, differences may exist beyond the 2 nd decimal place. Note 2: For relevance and specification, the Nigeria data were 
singled for explanation and analysis. Also, for comparism, the first and last countries in the ratings were listed in the table.

Safety and rule of law is measured through the indicators of rule of law, accountability, personal safety and national security. Evidently, Nigeria ranked 37th of the 54 countries with 46.4/100.0 recording a decline of -3.5 in the last 10 years (2007-2016) and an annual average of -0.39 over the same period. It shows a growth of +4.0 over 5 year trend (2012-2016) and +1.00 annual average trends signaling a bouncing back of safety and rule of law. However, the African average shows a slowing deterioration with 52.8/100.0 in 2016.

Table 5. Rule of Law

\begin{tabular}{l|l|l|l|l|l|l}
\hline 2016 & 2016 & $10-$ Year & $\begin{array}{l}\text { Annual } \\
\text { Average } \\
\text { Rank/54 } \\
\text { Score/100.0 } \\
(2007-2016)\end{array}$ & $\begin{array}{l}\text { 5-Year } \\
\text { Trend } \\
(2007-2016)\end{array}$ & $\begin{array}{l}\text { Annual } \\
\text { Average } \\
\text { Trend } \\
(2012-2016)\end{array}$ & $\begin{array}{l}\text { Indicator } \\
\text { performance }\end{array}$ \\
\hline $\begin{array}{l}1 \\
\text { SouthAfrica }\end{array}$ & 94.7 & +2.7 & +0.30 & +2.7 & +0.68 & $\begin{array}{l}\text { Increasing } \\
\text { improvement }\end{array}$ \\
\hline 14 Nigeria & 63.1 & +4.3 & +0.48 & +12.4 & +3.10 & $\begin{array}{l}\text { Increasing } \\
\text { improvement }\end{array}$ \\
\hline 54 Somalia & 8.7 & +0.9 & +0.10 & +0.9 & +0.23 & $\begin{array}{l}\text { Increasing } \\
\text { improvement }\end{array}$ \\
\hline $\begin{array}{l}\text { African } \\
\text { Average }\end{array}$ & 53.2 & 0.0 & 0.00 & +2.0 & +0.50 & $\begin{array}{l}\text { Bouncing } \\
\text { back }\end{array}$ \\
\hline
\end{tabular}

Source: IIAG, 2017.

Note 1: if annual trend appears the same in the two time periods, differences may exist beyond the 2nd decimal place. Note 2: For relevance and specification, the Nigeria data were singled for explanation and analysis. Also, for comparism, the first and last countries in the ratings were listed in the table.

Rule of law is measured through the judicial independence, judicial process, access to justice, property rights, transfers of power and multilateral sanctions. Nigeria ranked 14th of 54 African countries scoring 63.1/100.0 in 2016. It has a +4.3 growth in trend over 10 years (2007 - 2016) and +0.48 annual average trend over the same period. It has +12.4 growth over the last 5 years (2012-2016) and +3.10 annual average trend over the same period. It thus shows an increasing improvement in indicator performance. Generally, Africa's average is 53.2 and the continental indicator performance shows rule of law bouncing back in Africa after various experiences with colonialism, apartheid, wars, terrorism, and military intervention among others had bastardised existing traditional institutions of law. 
Table 6. Accountability

\begin{tabular}{l|l|l|l|l|l|l}
\hline $\begin{array}{l}2016 \\
\text { Rank/54 }\end{array}$ & $\begin{array}{l}2016 \\
\text { Score/100.0 }\end{array}$ & $\begin{array}{l}\text { 10-Year } \\
\text { Trend } \\
(2007-2016)\end{array}$ & $\begin{array}{l}\text { Annual } \\
\text { Average } \\
\text { Trend } \\
(2007-2016)\end{array}$ & $\begin{array}{l}\text { 5-Year Trend } \\
(2012-2016)\end{array}$ & $\begin{array}{l}\text { Annual } \\
\text { Average } \\
\text { Trend } \\
(2012-2016)\end{array}$ & $\begin{array}{l}\text { Indicator } \\
\text { performance }\end{array}$ \\
\hline $\begin{array}{l}1 \\
\text { Rwanda }\end{array}$ & 72.1 & +15.8 & +1.76 & +12.2 & +3.05 & $\begin{array}{l}\text { Increasing } \\
\text { improvement }\end{array}$ \\
\hline $\begin{array}{l}31 \\
\text { Nigeria }\end{array}$ & 32.7 & +6.5 & +0.72 & +5.2 & +1.30 & $\begin{array}{l}\text { Increasing } \\
\text { improvement }\end{array}$ \\
\hline $\begin{array}{l}54 \\
\text { Somalia }\end{array}$ & 1.6 & -1.7 & -0.19 & -5.1 & -1.28 & $\begin{array}{l}\text { Increasing } \\
\text { Deterioration }\end{array}$ \\
\hline $\begin{array}{l}\text { African } \\
\text { Average }\end{array}$ & 35.8 & +0.6 & +0.07 & +0.1 & +0.03 & $\begin{array}{l}\text { Slowing } \\
\text { Improvement }\end{array}$ \\
\hline
\end{tabular}

Source: IIAG, 2017.

Note 1: if annual trend appears the same in the two time periods, differences may exist beyond the 2 nd decimal place. Note 2: For relevance and specification, the Nigeria data were singled for explanation and analysis. Also, for comparism, the first and last countries in the ratings were listed in the table.

Accountability is measured through access to information, online public services, public sector accountability and transparency, accountability of public officials, corruption in government and public officials, diversion of public funds and corruption investigation. Nigeria is ranked 31st of 54 African countries and scores 32.7/100.0. Over annual and 10 years trend (2007-2016), it recorded +0.72 and +6.5 growth respectively. And the 5 year and annual trend (2012-2016) shows improvement of +5.2 and +1.30 growth. Africa's average is thus put at 35.8, showing a slowing improvement in continental indicator performance

Table 7. Personal Safety

\begin{tabular}{l|l|l|l|l|l|l}
\hline $\begin{array}{l}2016 \\
\text { Rank/54 }\end{array}$ & $\begin{array}{l}2016 \\
\text { Score/100.0 }\end{array}$ & $\begin{array}{l}\text { 10-Year } \\
\text { Trend } \\
(2007-2016)\end{array}$ & $\begin{array}{l}\text { Annual } \\
\text { Average } \\
\text { Trend } \\
(2007-2016)\end{array}$ & $\begin{array}{l}\text { 5-Year Trend } \\
(2012-2016)\end{array}$ & $\begin{array}{l}\text { Annual } \\
\text { Average } \\
\text { Trend } \\
(2012-2016)\end{array}$ & $\begin{array}{l}\text { Indicator } \\
\text { performance }\end{array}$ \\
\hline $\begin{array}{l}\text { Mauritius } \\
\text { N3 }\end{array}$ & 67.8 & +2.7 & +0.30 & -3.9 & -0.98 & $\begin{array}{l}\text { Warning } \\
\text { Signs }\end{array}$ \\
\hline $\begin{array}{l}\text { Nigeria } \\
\text { Somalia }\end{array}$ & 38.3 & -1.7 & -0.19 & +8.0 & +2.00 & $\begin{array}{l}\text { Bouncing } \\
\text { Back }\end{array}$ \\
\hline $\begin{array}{l}\text { African } \\
\text { Average }\end{array}$ & 45.7 & -7.1 & -0.79 & -4.3 & -1.08 & $\begin{array}{l}\text { Increasing } \\
\text { deterioration }\end{array}$ \\
\hline
\end{tabular}

Source: IIAG, 2017.

Note 1: if annual trend appears the same in the two time periods, differences may exist beyond the 2nd decimal place. Note 2: For relevance and specification, the Nigeria data were singled for explanation and analysis. Also, for comparism, the first and last countries in the ratings were listed in the table.

This is measured through safety of the person, police services, social unrest, crime, political 
violence and human trafficking. However, Nigeria ranked 43rd out of the 54 African countries. Over 10 years and annual trend (2007-2016), it has -1.7 and -0.19 respectively. Interestingly, the last 5 years (2012-2016) shows +8.0 and an annual of +2.00 signaling bouncing back and improvement in personal safety index. Africa's average records 45.7 in 2016 representing a slowing deterioration from previous experiences.

Table 8. National Security

\begin{tabular}{|c|c|c|c|c|c|c|}
\hline $\begin{array}{l}2016 \\
\text { Rank/54 }\end{array}$ & $\begin{array}{l}2016 \\
\text { Score/100.0 }\end{array}$ & $\begin{array}{l}\text { 10-Yyear } \\
\text { Trend } \\
(2007-2016)\end{array}$ & $\begin{array}{l}\text { Annual } \\
\text { Average } \\
\text { Trend } \\
(2007-2016)\end{array}$ & $\begin{array}{l}\text { 5-Year } \\
\text { Trend } \\
(2012-2016)\end{array}$ & $\begin{array}{l}\text { Annual } \\
\text { Average } \\
\text { Trend } \\
(2012-2016) \\
\end{array}$ & $\begin{array}{l}\text { Continental } \\
\text { Indicator } \\
\text { Performance }\end{array}$ \\
\hline $\begin{array}{c}1 \\
\text { Botswana }\end{array}$ & 100.0 & 0.0 & 0.00 & 0.0 & 0.00 & No change \\
\hline $\begin{array}{l}1 \text { Cabo } \\
\text { Verde }\end{array}$ & 100.0 & 0.0 & 0.00 & 0.0 & 0.00 & No Change \\
\hline $\begin{array}{c}1 \\
\text { Mauritius }\end{array}$ & 100.0 & +5.0 & +0.56 & 0.0 & 0.00 & No Change \\
\hline $\begin{array}{c}1 \\
\text { Seychelles }\end{array}$ & 100.0 & +0.3 & +0.03 & +0.2 & +0.05 & $\begin{array}{l}\text { Increasing } \\
\text { Improvement }\end{array}$ \\
\hline 47 Nigeria & 51.5 & -23.0 & -2.56 & -9.6 & -2.40 & $\begin{array}{l}\text { Slowing } \\
\text { deterioration }\end{array}$ \\
\hline $\begin{array}{l}54 \text { South } \\
\text { Sudan }\end{array}$ & 18.3 & -- & -- & -36.5 & -9.13 & $\begin{array}{l}\text { Increasing } \\
\text { deterioration }\end{array}$ \\
\hline $\begin{array}{l}\text { African } \\
\text { Average }\end{array}$ & 76.4 & -3.7 & -0.41 & -3.8 & -0.95 & $\begin{array}{l}\text { Increasing } \\
\text { deterioration }\end{array}$ \\
\hline
\end{tabular}

Source: IIAG, 2017.

Note 1: if annual trend appears the same in the two time periods, differences may exist beyond the $2^{\text {nd }}$ decimal place. Note 2: For relevance and specification, the Nigeria data were singled for explanation and analysis. Also, for comparism, the first and last countries in the ratings were listed in the table.

National security is measured by government involvement in armed conflict, domestic armed conflicts, violence by non state actors, cross border tensions, internally displaced people and political refuge. Interestingly, Botswana, Cabo Verde, Mauritius and Seychelles were jointly ranked 1 st but specifically in measuring national security, Nigeria ranked $47^{\text {th }}$ out of the 54 African countries. It has a score of 51.5/100.0 and -23.0 and -2.56 for 10 year and annual trends for the year (2007-2016). The last 5 years and annual records (2012-2016) reveal the nation recorded -9.6 and -2.40 respectively indicating slowing deterioration on indictor performance. Also, African average of $76.4 / 100.0$ is only best enough to indicate an increasing deterioration of national security in the continent.

\section{Assessing Nigerian Nation in the Fourth Republic}

Langenhove (2004) opines that the nature of domestic politics in the majority of African countries is based on political clientelism and neo-patrimonilism that have not catered for the efficient political and economic management of the state, hence, compounding the human security problems. From the foregoing (WGI, 2010 and IIAG, 2017) and according to the Global Human Security Index (2011) Nigeria ranks 212 out of 233 countries examined 
(Human Security measured by considering indices around economic, environment and social fabric). Also, evidence from events in the country shows that Nigeria ranks significantly low and poor in the areas of governance, human security, safety and rule of law despite the national efforts in recent times (the Transformation Agenda 2011-2015 document and the Report on National Conference, 2014) to address the menace. Meanwhile, it is obvious that it is not the lack of initiatives or recommendations to confront it but the malfunctioning of government and the lack of political will to implement the recommendations.

Of note, human security complements state security, strengthens human development and enhances protection of human rights and having argued for the place of governance in human security and expressing an all-encompassing condition in which people and communities live in freedom, peace and safety, participate in political governance of their countries, enjoy fundamental human rights, access to resources and basic necessities of life, and habitable environment, the safety and rule of all in the state are thus mutually reinforcing. Thus, it is crucial that Nigeria does not further pacify human security challenges and governance narratives by ignoring political, human rights and economic responsibilities.

Collier (2004) argues that if human development is freedom from want, human security can be understood as the ability to pursue those choices in a safe environment and on equal basis with others. Thus, the concept of governance and human security holds that the state is responsive to its citizenry and is efficient with the obligation to provide an environment that allows equity and participation through democracy where human rights are explicitly guaranteed. Thus, the relationship between governance and human security in Nigeria is inextricable, yet, with immense challenges such as uncertain policy directives, pervasive poverty, challenging economy, insurgency and terrorism, religious and ethnic cleansing, and negative citizen perception of political leadership, violent elections among others which has further threatened and made vulnerable the core ingredients of rule of law. Therefore, the study is of the opinion that Nigeria as a nation has not done well in core areas of governance, human security and rule of law.

\section{Findings and Concluding Remarks}

While WGI acknowledged margin of error, it failed to clearly measure and present in clear terms the findings of each indicator by country. It also concentrated on resource rich vs non resource rich countries neglecting the fact that resources when not properly managed can lead to social agitation, uprising and collapse of government as witnessed recently in the Arab spring struggle (involving Libya, Tunisia, Egypt among others). Thus, the data were not enough for precise country rankings, but to highlight relative strengths and weaknesses for analytical and policy purposes. However, it gave a platform for comparism and explicated early signals and warnings for administrative and policy cautions.

Meanwhile, the WGI reports aggregate individual governance indicators for 214 economies globally over the period from 1996 to 2006 for six dimensions of governance covering: voice and accountability; political stability and absence of violence; government effectiveness; regulatory quality; rule of law; and control of corruption on the one hand, IIAG measures overall governance from safety and rule of law; participation and human right; sustainable 
economic opportunity; and human development in the 54 African countries on the other hand. The IIAG thus established a far-reaching and dependable performance indicator credible enough to understand safety and rule of law in Nigeria as well as Africa as a whole.

In conclusion, although human security and governance are deeply interconnected, both are concerned with identifying a rudimentary set of universal concerns that span poverty and violence. Alkire (2003) expresses that human security is deliberately protective and recognizes that the people and communities are fatally threatened by events well beyond their control. Thus, the strengthening of democratic institutions and enhancement of rule of law through unhindered participation and censoring as well as openness for improved citizen participation and involvement can enhance service delivery by government and ensured safety, legal restraints on government officials and maintain order to coordinate behaviour and transactions among the citizens.

The study however recommends a tripartite approach at both sub national and national levels to include: political, economic and social considerations through thorough assessment of the vulnerabilities and the capacities to prevent and mitigate the recurrent insecurities as well as critical note that consciousness of governments to human security issues is capable of (re)enforcing, (re)orientating and (re)directing government's agenda while (re)setting its programmes and (re)settling the aggrieved.

\section{References}

Akokpari, J. (2007). The Political Economy of Human Insecurity and Sub-Saharan African, Institute of Developing Economics, Japan External Trade Organisation

Alkire, S. (2003). A Conceptual Framework for Human Security, University of Oxford, Centre for Research on Inequality, Human Security and Ethnicity, CRISE

Alok, K. Y. (n.d). Rule of Law, International Journal of Law and Legal Jurisprudence Studies, 5(30), 205-220.

Annan, K. (2006). Statement on Human Rights Day 2006 by United Nations Secretary General, http://www.un.org/democracyfurd/XNewsitamaRightsDay.html

Chitiyo, K. (nd). African Security and the Securitization of Development, Africa Programme

Cillers, J. (2004). Human Security in Africa: A Conceptual Framework for Review, A Monograph for the African Human Security Initiative

Decentralisation Finance and Management. (1997). USAID Governance Initiative in Nigeria: A Strategic Associate of Primary Healthcare and Local Government in Rural Development, Inc, African Bureau Working Paper on the Concept of Governance and its Implications for Aids/Development Assistance Programme in Africa.

DesGasper, D. (2014). Human Security Analysis as a Framework for Value-Oriented Governance- The Example of Climate Change, Netherlands, International Institute of Social Studies 


\section{Macrothink}

Journal of Public Administration and Governance ISSN 2161-7104 2018, Vol. 8, No. 2

European Commission for Democracy through Law. (2016). Rule of Law Checklist, Venice Commission and Council of Europe, www.coe.int

European Commission. (2006). Communication on Governance: The European Consensus on Development, Com 2006, 421 p3.

Fukuyama, F. (2013). What is Governance? Centre for Global Development (CGD), Working Paper 314, Washington DC, Centre for Global Development

Gilles, O. (2016). Peace and Security in Africa, Milano, Italian Institute for International Political Studies

Goldstone, J. (nd). Population and Security.

Hager, M. (2000). The Rule of Law: Defining it and Defending it in the Asian Context, in The Rule of Law Perspectives from the Pacific Rim, The Mansfield Centre for Pacific Affairs

Hank, D. (2005). Human Security Relevance and Implications Parameters: US Army War College, 15(2), 91-106.

Henk, D. (2001). Security in Africa, Occasional Paper N0 1 "Security: A New African Paradigm. www.uz.ac.zw/units/cds/occasional/paper/"

Hope, K. (2005). Towards Good Governance and Sustainable Development: The African Peer Review Mechanism on Governance. International Journal of Policy, Administration and Institutions, 08(2).

Hussein, K., Gnisci, D., \& Wanjim, J. (2004). Security and Human Security: An Overview of Concepts and Initiatives. What Implications for West Africa? Saheel and West Africa Club

Institute for Security Studies. (2013). Improving Human Security in Africa: Pretoria, ISS Annual Review

Kaufmann, D. (2005). Myths and Realities of Governance and Corruption, Washington DC, World Bank

Kaufmann, D. (2010). The Worldwide Governance Indicators: Methodology and Analytical Issues. Global Economy and Development at BROOKINGS

Kaufmann, D., Kraay, A., \& Mastruzzi, M. (2010). The Worldwide Governance Indicators: Methodology and Analytical Issues, Policy Research Working Paper 5430, World Bank, Development Research Group: macroeconomics and Growth Team

Langenhove, L. (2004). Regionalizing Humans Security in Africa, Tokyo, Paper for the United Nations University-Corporate Regional Integration Studies

Lodgaard, S. (2000). Human Security: Concept and Operationalization" Paper Presented at the Expert Seminar on Human Rights and Peace, Geneva, 8-9 December

Maesen, L., \& Walker, A. (2014). The Development of Social Quality between 1994 and 2014. Working Paper 13, The Hague: International Association in Social Quality 
Oberleitner, G. (2005). Human Security: “A Challenge of International Law?” Global Governance, 11(2), 5-203.

Okeke, E. (2010). The Challenges of Governance in Nigeria: Broad Perspective and Implications for the Engineering Practice: Abuja, Association of Consulting Engineers

Olaniyan, A. (2011). The Demographic Nightmare: Population Boom and Security Challenges in Africa, In Sharamo, R and Ayangafaccds (ed), The State of Human Security in Africa: An Assessment of Institutional Preparedness, Pretoria, Institute for SECURITY Studies

Omodia, S. M., \& Aliu, M. (2013). Governance and Threat to National Security in Emerging Democracies: A focus on the Nigerian Fourth Republic, Research on Humanities and Social Sciences, 3(4).

Raeymaekers, T., Menkhans, K., \& Vlassenroot, K. (2008). State and Non-state Regulation in African Protracted Crises: Governance without Government, Afrika Focus, 21(2).

Security Council Report. (2011). Emerging Securities Threats in West Africa, www, securitycouncilreport.org

Sharamo, R., \& Ayangafac, C. (2011). The State of Human Security in Africa: An Assessment of Institutional Preparedness in Sharamo, R and Ayangafac, C (eds) The State of Human Security in Africa: An Assessment of Institutional Preparedness, Pretoria, Institute for Security Studies

Tamanaha, B. (2007). A Concise Guide to the Rule of Law, St John's University School of Law. http://ssrn.com/abstract=1012051

Thomas, M. (2006). What do the Worldwide Governance Indicators Measure?, Johns Hopkins University, The Paul H. Nitze school of Advanced International Studies

Tschirgi, N. (2011). The Security-Development Nexus: from Rhetoric to Understanding Complex Dynamics, in McCandles, E and Kavbo, T, (eds) Peace, Conflict and Development in Africa: A Reader, Switzerland, University for Peace

United Nations Commission Report (2003).

United Nations Development Programme (1994). Human Development Report, New York, Oxford University Press

United Nations Development Programme (1995). Human Development Report (1995). New York, Oxford University Press

United Nations Development Programme (2006). Strategy Note on Governance for Human Development, New York, Governance Indicators, A user's Handbook

Urry, J (2014). Thinking Society Anew. Reprinted in Beck, Ulrich Beck: Pioneer in Cosmopolitan Sociology and Risk Society. Heidelberg: Springer. PP v-xi www.govindicatord.org WGI/ World Bank, 2016. 


\section{Copyright Disclaimer}

Copyright for this article is retained by the author(s), with first publication rights granted to the journal.

This is an open-access article distributed under the terms and conditions of the Creative Commons Attribution license (http://creativecommons.org/licenses/by/4.0/). 